\section{Herbs and Aromatics}

\section{Jeanine M. Davis}

| 1987, the only extension information on herbs available from the Dept. of Horticultural Science at North Carolina State Univ., Raleigh, was an old leaflet on growing herbs in the home garden. County extension agents complained that they received many requests for commercial herb production information, but they did not have the training or the resources to answer the questions. In 1988, the extension herb program was initiated at North Carolina State Univ. Following is a description of the step-by-step plan used to develop a successful extension herb program. Although this is a statewide program, it could also be used as a county or regional program.

Interest in growing and using herbs is increasing throughout the United States. This is reflected in the large number of newsletters, books, and magazines that are available on the topic. Many of these publications, however, are written for home gardeners or hobbyists. Although research on herbs has increased in recent years, papers in scientific journals usually contain information of interest primarily to horticulturists or large-scale producers. Practical cultural information for small-scale, commercial herb producers is limited. Inaddition, thecultural information that is available may not be suitable for growing conditions in other areas.

The first step in developing the North Carolina extension herb program was to assess the present local situation; i.e., visit the growers. Operations of all sizes were visited; large, well-established ones, small profitable ones, ones that were just getting started, and some that were failing. Careful notes were taken on the successes and failures, what the primary production problems were, how marketing was handled, and what growers wanted from the extension service.

The next step was to examine extension programs and materials from other states. For example, The Herb, Spice and Medicinal Plant Digest published by the Univ. of Massachusetts Cooperative Extension System (Craker and Simon, 1992) contains information on production, science, and recent literature on herbs. The Virginia Creeper (Hankins, 1991) published by the Virginia Cooperative Extension Service, often contains very practical information on small-scale herb production and marketing.

Department of Horticultural Science, Mountain Horticultural Crops Research and Extension Center, North Carolina State University, 2016 Fanning Bridge Road, Fletcher, NC 28732.
The national herb situation was studied by attending conferences such as the annual meeting of the International Herb Growers and Marketers Assn. (IHGMA) (1990). These meetings provide excellent opportunities to talk with people in the industry; to interact with researchers and other extension personnel; and to learn about the most recent research findings, market trends, production problems, and business success stories related to herbs. IHGMA also publishes proceedings for each annual meeting (Simon et al., 1990). These proceedings contain a wealth of information on all aspects of the herb industry, including propagation, greenhouse production, business concerns, marketing, decorative herbs, culinary herbs, medicinal herbs, and herbs for essential oils. Many of the papers are written by growers and business people and contain easy-to-understand, practical information,

In North Carolina, a herbassociation was already established when the extension herb program was initiated. The North Carolina Herb Assn. (NCHA) was organized in 1985 with theassistance of a marketing specialist from the North Carolina Dept. of Agriculture. Originally, the association consisted mostly of hobbyists, herb craft makers, and herbalists. The association held a fall conference with an educational program and a summer "Wild Herb" weekend, which was mostly recreational. A quarterly newsletter also was published. Like the extension service, however, the association noted an increased demand for more practical information on commercial production and marketing.

At this point, I offered to assist the association and was invited to attend all board meetings. A symbiotic relationship quickly developed. The association benefited from the assistance I provided, such as promoting their activities, helping them develop and prioritize goals, and preparing two directories, which are described later. In return, I had a means of communicating and working with a large number of herb growers in the state.

Image was important to the association and needed to be upgraded. The newsletter was revised to look more professional and to address the needs of a more diverse audience. The annual conference was expanded to provide more information on commercial herb production, including market development and small business tax information. The NCHA conference evolved to the extent that it is the major herb education meeting in the state. I promote it as such, and do not need to hold a separate state extension herb meeting.

The association expressed the need to increase the visibility of the herb industry in North Carolina. As part of this effort, the North Carolina Herb Association Herb Farm and Garden Directory (Davis, 1992) was prepared. It contains a map indicating the locations of herb farms and gardens across the state and is being distributed through state welcome centers and at motels, restaurants, and tourist information booths. The layout and artwork for the brochure was saved on a computer disk so that next year a member of the association can easily update the brochureand have itreprinted.

The association also expressed a need for a means of networking among the members; to exchange products, plants, or information with other members. Therealso was a desire to obtain wholesale discounts by getting together to order supplies in bulk. In response to these needs, a member business directory was developed. This was accomplished by distributing a questionnaire to all NCHA members in one of the newsletters. The completed questionnaires then were compiled into a directory that, for each business, lists the herb plants grown, products made, other herb and herb-related products sold, markets, services offered, special events held, materials that may be group-purchased, and items commonly bought that other members may sell. This directory serves as the primary networking tool for the association and already has resulted in increased membership. The formation of a regional chapter of the association in the western part of the state also has helped improve networking among members.

Herb demonstration gardens have been established at a university research station and several county extension offices across the state. I maintain one of these gardens, but others are maintained by county agents and Master Gardeners. Demonstration gardens can be located in almost any public place (e.g., in a park, near municipal buildings, or on the grounds of a community college or university). Although easy to establish, arrangements need to be made for routine watering and weeding. Besides Master Gardeners, other volunteers may be recruited from local garden clubs or herb societies.

Demonstration gardens serve many purposes By growing different herbs, you become familiar with them, learn how to produce them, and discover what some of the problemsare. They also serve as public relations tools. Such a demonstration is maintained at the Mountain Horticultural Crops Research Station in western North Carolina. It is called the "Touch and Smell Garden." People are encouraged to walk through the garden and pickleaves to crush and smell. The plants are identified with common name, botanical name, and a brief description of uses. This demonstration also has been useful for agent in-service training sessions, field days, workshops, and for tours by groups of garden club members and school children

County agents receive many requests for information on herbs. Four years ago in North Carolina, there was no extension information available on herbs. To quickly fill this void, initially a herb article was included in the monthly vegetable extension newsletter, Veg--INews (Wilson, 1990) which is sent to all county agents and specialists in the state. The information for these articles was obtained from published sources, such as Sweet Basil: Production Guide (Simon, 1985), The Herb, 
Spice and Medicinal Plant Digest, (Craker and Simon, 1992) and a few books that growers had recommended, [e.g., Herbal Bounty (Foster, 1984) Rodale's Illustrated Encyclopedia of Herbs (Kowalchik and Hylton, 1987) and The Potential of Herbs as a Cash Crop (Miller, 1985)]. In addition, information was provided based on the experiences of some commercial herb growers and the new research program. Slide sets, with examples of many herbs and general herb culture, also were quickly developed for agents to use in their county programs.

As information on production of a specific herb was gathered from research, experience, and advice from established producers, 1- to 2-page production leaflets were written. With desktop publishing, these were produced efficiently and easily updated. For many herbs, these are not cookbook-style production guides. Pest control sections, in particular, are quite different from what is found in a standard vegetable production guide. Few agricultural chemicals are registered for use on herbs. Therefore, preventive control measures are recommended. Growers areencouraged to use good cultural practices-crop rotations, cover crops, manures, and diversified plantings. If problems are encountered, organic controls are recommended first. Growers are reminded that organic controls are not necessarily safe or legal. A commercial pest-control product, organicor not, must be registered for use on the crop.

As a specialist, a very important step in building an herb extension program was countyagent training. Many agents in North Carolina had no previous experience with herbs. They often felt intimidated when a client walked in with a plant they did not even recognize. It was important to impress upon agents that just because the crop was new to them did not mean they were unqualified to advise people on how to grow it. They needed to be reminded that all their previous training on plant pathology, soil fertility, entomology, weed control, and basic cultural practices was still valid.

The first county agent training session that included herbs was a full-day session on shiitake mushroomsand herbs. The first half of the day was spent in the classroom. Specialists discussed disease control, insect control, general production practices, and marketing. The rest of the day was spent touring research and demonstration beds on a research station. Demonstration beds were visited to see how the plants looked in the field and to touch and smell them. We tried to get the agents excited about herbs by telling them about herb uses and folklore. In the greenhouse, demonstrations were given on propagation techniques and information was provided on what can be grown from cuttings or seeds, and where to obtain plants. The following year, herbs were included in two in-service training sessions on specialty-vegetable production. Both sessions consisted solely of farm visits. Some new producers were visited to show the size of operations many people begin with when they grow herbs. Herb growers had complained that some agents did not take their requests for help seriously because their herb plantings were so small. Agents are accustomed to working with traditional vegetable crops grown on fairly large acreages. To many agents, an operation consisting of $<5$ acres looks like a hobby; yet, several of our most successful herb businesses began with less than a quarter of an acre of herbs. Economicsand marketing were stressed throughout these sessions as well.

People in the early stages of deciding whether or not to grow herbs often do not have a good idea of what is involved-how much space or labor it takes to grow herbs, common production problems, marketing needs, equipment required, etc. In North Carolina, several established growers reported an interest in using drip irrigation, but did not know how to install a small system at an affordable price. On-farm tests were used to educate both groups. A small-scale drip irrigation system for basil, production of basil on black plastic, woodland production of goldenseal, and elephant garlic production were all demonstrated inon-farm tests. Agents were encouraged to include these tests in their field days and to publicize them in newspaper articles, on flyers, to gardening clubs, and in radio spots.

Public workshops on various aspects of herb production also have been conducted. Specialists spoke on various aspects of production and current research, and growers talked about their experiences. Sessions on herbs also have been included at statewide and regional vegetable, greenhouse vegetables, and small and part-time farmers meetings. During the recent NC. Ginseng Conference, the decision was made to start a NC. Ginseng Assn.

Workingwith the North Carolina herb industry, I quickly discovered that the production information needed by the industry was not available. A research program was initiated to develop cultural recommendations for North Carolina. For example, for fresh market basil pro-ducers, research was conducted on row-spacing, varieties, and mulches. Overwintering studies were conducted on lemon verbena. For commercial ele-phant garlic production, source of planting stock, clove size, planting date, and nitrogen fertilization rates have been examined.

Marketing of a specialty crop, such as herbs, isdifficult. Of all the herbs, ginseng is probablythe easiest to sell because, in North Carolina, buyers must be registered with the state. It is a simple task to take a sample of roots to various buyers on the list, Also, ginseng is dried and will keep until the right buyer and the right price are found. For fresh herbs, marketing can be much more complicated. Many small producers deliver their herbs directly to restaurants. Tailgate markets and farmers' markets are other popular outlets for small amounts of fresh herbs. These sales techniques take time, however, and many growers find these outlets limit the volumes they can handle. Some areas have wholesalers or brokers who specialize in specialty and organic produce, but many areas do not. It was important to stress the problems of marketing at all meetings and training sessions. Selling fresh herbs is not like selling tomatoes or cabbage. It takes marketing know-how, perseverance, creativity, and the right personality to be successful.

As with most small businesses, many individuals wanting to grow herbs have no business background. Information on how to start a business, prepare a business plan, obtain financing, keep farm and business records, and evaluate progress should be made available. This information can be provided at workshops or in publications In North Carolina, there are a number of publicand private associations devoted to helping small businesses; potential herb growers are encouraged to seek their services.

To improve the market potential for herbs, we have tried to educate the public about the uses of herbs and where they can buy herbs and herb products locally. The NC. Cooperative Extension Service, NC. Herb Assn., and NC. Dept. of Agriculture have co-sponsored "Herb Days" at several state farmers' markets. At Herb Days, local producers pay a nominal price for a booth and sell herb plantsand products such as vinegars, teas, jellies, wreaths, and potpourri. Herb Days are held in the spring when herb plants sell well and in the fall when tourists visit the mountains to view fall colors and look for unique Christmas gifts. During Herb Days, demonstrations are presented on a variety of herb topics, such as how to cook with herbs, how to plant an herb garden, and herbal lore. These demonstrations are given by growers and extension personnel. An extension booth with herb specimensand production information is set up at most of the Herb Days.

Finally, herb production bulletins are being published. In addition to the standard peer-review process, growers review the manuscripts for practicality and completeness. Ginseng: A Production Guide for North Carolina (Konsler, 1992) has been revised and published. The North Carolina Basil Production Guide (Davis, 1992) has just been published. Videotapes also are being produced because of their popularity with agents for use in meetings and with individuals to view at their leisure.

In summary, the steps used to start the extension herb program in North Carolina were:

1) Assess the local situation through grower visits and discussions with people involved in the industry.

2) Assess the national situation by attending national herb meetings and investigating herb extension programs in other states.

3) Become involved with the state commodity association.

4) Construct herb demonstration gardens.

5) Publish articles in the state vegetable newsletter to quickly provide agents with information 

ings.

6) Prepare slide sets for use at county meet-

7) Produce 1- to 2-page production leaflets.

8) Conduct in-service county agent training sessions to familiarize agents with herbs and teach them how to use their basic horticultural training to handle questions.

9) Conduct on-farm tests to demonstrate new technologies to growers.

10) Hold public workshopsand conferences.

11) Conduct research to address common production problems.

12) Provide marketing information.

13) Direct growers to organizations that provide business start-up information.

14) Educate the public about herbs and herb products through herb days and festivals.

15) Produce herb production bulletins and videotapes.

\section{Literature Cited}

Craker, L.E. and J.E Simon (eds.). 1992. The herb, spice and medicinal plant digest. Univ. of Massachusetts Coop. Ext. Syst., Univ. of Massachusetts, Amherst.

Davis, J.M. 1992, North Carolina basil production guide. AG-477. N.C. Coop. Ext. Service, NC. State Univ., Raleigh.

Davis, J. 1992. North Carolina Herb Association herb farm and garden directory. N.C. Herb Assn., Godwin, N.C.

Foster, S. 1984. Herbal bounty. Gibbs M. Smith, Inc., Peregrine Smith Books, Salt Lake City.

Hankins, A. 1997. The Virginia creeper. Virginia Coop. Ext. Service, Virginia State Univ., Petersburg.

Kowalchik, C. and W.H. Hylton (eds.). 1987. Rodale's encyclopedia of herbs. Rodale Press, Emmaus, $\mathrm{Pa}$.
Konsler, T.R. 1992 Ginseng: A production guide for North Carolina. Rev. by J.M. Davis. North Carolina Coop. Ext. Service, North Carolina State Univ., Raleigh. AG-323.

Miller, R.A. 1985. The potential of herbs as a cash crop. Acres U.S.A., Kansas City, Miss.

Simon, J.E 1985. Sweet basil: A production guide. Coop. Ext. Service, Dept. of Horticulture, Purdue Univ., West Lafayette, Ind.

Simon, J.E., A. Kestner, and M.R. Buehrle (eds.). 1990. Proc. Annu. Conf. Intl. Herb Growers and Marketers Assn., Silver Springs, $\mathrm{Pa}$.

Wilson, L.G. (ed.) 1990 .Veg-I-News. North Carolina Agr. Ext. Serv., Dept. Horticultural Science, North Carolina State Univ., Raleigh. 